\title{
Removal of nickel from lixivium of slag of scrap copper smelting Zheng $\mathrm{Xu}^{\mathrm{a}}$, Yan Huangfu ${ }^{\mathrm{b}}$, Yan $\mathrm{Li}^{\mathrm{c}}$ \\ General Research Institute for Nonferrous Metals, No. 2 Xinjiekou Wai Street, Beijing, 100088, China \\ axzh63@126.com, ’huangfuyan927@126.com, 'ly_wolfish@163.com
}

Keywords: nickel, scrap copper smelting, slag, lixivium

\begin{abstract}
The content of nickel in the lixivium of scrap copper smelting slag reaches $640 \mathrm{mg} / \mathrm{l}$ while the zinc content is more than $100 \mathrm{~g} / \mathrm{l}$. This high content of nickel in the solution must not only be separated from the leachate for resource recovery, but also for the subsequent zinc electrowinning which need to keep the nickel content less than $1 \mathrm{mg} / \mathrm{l}$ to make the electrowinning process carrying out regularly. The lixivium was pretreated by zinc powder and most of the copper and cadmium was precipitated and the nickel content was reduced to $8 \mathrm{mg} / \mathrm{l}$. Then the antimony salt method was used to separate the remanent nickel. After a series of experiment, the nickel was reduced to $0.9 \mathrm{mg} / \mathrm{l}$ to meet the zinc electrowinning standard under the best condition at $95^{\circ} \mathrm{C}, 350 \mathrm{r} / \mathrm{min}$ stirring speed, $10 \mathrm{~g} / \mathrm{l}$ of zinc powder, $6 \mathrm{mg} / \mathrm{l}$ of Sb2O3 and 60min of reaction time. The removed nickel will be refined by further metallurgic method.
\end{abstract}

\section{Introduction}

At present, the copper recycling industry is developing rapidly in China and it produces large amounts of slag at the same time. The contents of valuable metal ions in this type of slag are much more than the conventional copper smelting slag. After sulfuric acid leaching, the content of nickel is also high in the lixivium. The aim of the research is to reduce the content of nickel which should be lower than the standard of the zinc industrial electrowinning by purification and separation process.

\section{Experimental materials and methods}

In this paper, the lixivium of slag comes from Ningbo Jintian Copper Corp. The ingredients in the solution are shown in table 1. A large quantity of copper, zinc and nickel was contained in the lixivium with high recovery value.

Table 1. Multielement analysis result

\begin{tabular}{llllll}
\hline $\mathrm{Ni}$ & $\mathrm{Co}$ & $\mathrm{Fe}$ & $\mathrm{Cd}$ & $\mathrm{Cu}$ & $\mathrm{Zn}$ \\
\hline $0.64 \mathrm{~g} / \mathrm{l}$ & $11.24 \mathrm{mg} / \mathrm{l}$ & $8.98 \mathrm{mg} / \mathrm{l}$ & $0.4 \mathrm{~g} / \mathrm{l}$ & $0.41 \mathrm{~g} / \mathrm{l}$ & $130 \mathrm{~g} / \mathrm{l}$ \\
\hline \hline $\mathrm{As}$ & $\mathrm{Sb}$ & $\mathrm{SiO3}^{2-}$ & $\mathrm{F}$ & $\mathrm{Cl}$ & \\
\hline$<1.0 \mathrm{mg} / \mathrm{l}$ & $14.56 \mathrm{mg} / \mathrm{l}$ & $62.92 \mathrm{mg} / \mathrm{l}$ & $68.0 \mathrm{mg} / \mathrm{l}$ & $13.6 \mathrm{~g} / \mathrm{l}$ & \\
\hline
\end{tabular}

\section{Results and discussion}

The lixivium of slag of scrap copper smelting contains large amount of copper and cadmium ions. The sample needs to be pretreated before it can be filtrated for separation. After purifying, the nickel in the lixivium was reduced.

The metal ions content of copper, cadmium and nickel level in the solution after processing was shown in table 2. After the pretreatment step, the content of nickel, copper and cadmium in the lixivium was $8.04 \mathrm{mg} / \mathrm{l}, 0.18 \mathrm{mg} / \mathrm{l}$ and $0.6 \mathrm{mg} / \mathrm{l}$ respectively. 
Table2. Copper and cadmium ions content after treatment $/ \mathrm{mg} \cdot \mathrm{l}^{-1}$

\begin{tabular}{llll}
\hline ions & $\mathrm{Cu} 2+$ & $\mathrm{Cd} 2+$ & $\mathrm{Ni2}+$ \\
\hline Residual concentration & 0.1 & 0.6 & 8.04 \\
\hline
\end{tabular}

Temperature on the research of the actual solution purification separation in addition to the nickel test

Experimental conditions and methods: A volume of 500ml pretreated lixivium was added into three-necked flask in the experiment, the recycling water was turned on then and the previous solution was heated at this time whilst $6 \mathrm{mg} / \mathrm{l} \mathrm{Sb2O3}$ was put into it. Starting stirring until the temperature is up to the anticipated point. Then the zinc powder was mixed which the addition was $5 \mathrm{~g} / \mathrm{l}$, and starting timing from then on. At the end of the experiment, some appropriate reacted solution was taken and then filtered and cooled off gradually, finally the analysis of the example was carried out. When the temperature up to $95^{\circ} \mathrm{C}$, the nickel rate of removing was at $76.38 \%$, and the nickel contained in the solution dropt below $1.63 \mathrm{mg} / \mathrm{l}$. However, as the temperature went up, the solution began to boil and the reaction would be difficult to control under the circumstances. As a result, the optimum reaction temperature point of the experiment was determined at $95^{\circ} \mathrm{C}$.

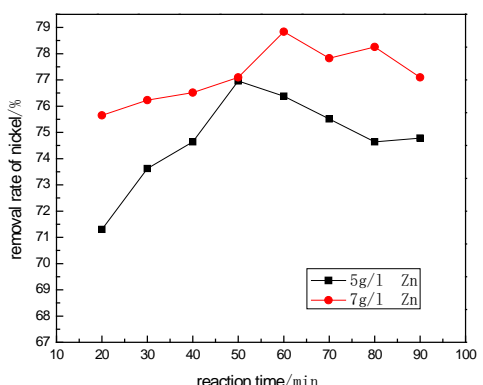

Fig. 1 The influence of reaction time on nickel purification separation

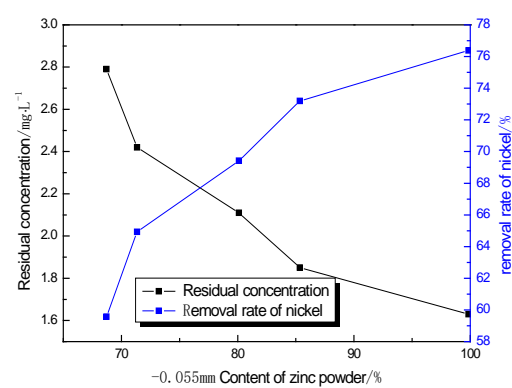

Fig.2 The influence of zinc powder granularity on nickel purification separation

\section{The reaction time to the actual solution purification separation in addition to the nickel test research}

According to the test results of temperature, the reaction temperature was set at $95^{\circ} \mathrm{C}$. A volume of $500 \mathrm{ml}$ pretreated solution was added into three-necked flask in the experiment, and the recycling water was turned on then and the lixivium was heated at this time with $6 \mathrm{mg} / \mathrm{l} \mathrm{Sb2O3}$ adding. When the temperature was risen to $95^{\circ} \mathrm{C}$, zinc powder was added into the lixivium respectively for $5 \mathrm{~g} / \mathrm{l}, 7$ $\mathrm{g} / \mathrm{l}$ in two experiments. Some appropriate reacted solution was taken and then filtered and cooled off gradually every 10 minutes, finally the analysis of the example was carried out.

As Fig. 1 shows that more quantities of the nickel were removal with the reaction time increased. When the reaction time was $60 \mathrm{~min}$, removal rate of nickel reached the highest. If the reaction time was continued to increase, the nickel inverse phenomenon appeared. Therefore, the test reaction time can be set for $60 \mathrm{~min}$.

\section{Zinc powder particle size on the research of the actual solution purification separation in} addition to the nickel test

The experiment was conducted under conditions at $95^{\circ} \mathrm{C}$, the addition of different particle size of zinc powder was $5 \mathrm{~g} / \mathrm{l}$ and the mixing amount of Sb2O3 was $6 \mathrm{mg} / \mathrm{l}$, when the temperature rise to 
$95^{\circ} \mathrm{C}$, added zinc powder slowly, and start timing at the same time, the reaction time was 60 min. The experimental result is given in figure 4.

As Fig. 2 shows, increasing quantities of the nickel were removed as the granularity of the zinc powder decreased. Residual concentration of nickel is fall during the process. When the content of $-0.055 \mathrm{~mm}$ level zinc powder was $99.85 \%$, the residual nickel content in the reaction solution was $1.63 \mathrm{mg} / \mathrm{l}$.

\section{Amount of zinc powder on the research of the actual solution purification separation in addition to the nickel test}

According to the temperature test results, it was determined that the experiment reaction was set at $95^{\circ} \mathrm{C}$.A sample of $500 \mathrm{ml}$ treated solution was acquired and joined in the neck bottle. The circulating water was started when solution was heated. A amount of $6 \mathrm{mg} / \mathrm{l} \mathrm{Sb2O3}$ was put into the bottle before the stirring process began. Until the temperature rise to $95^{\circ} \mathrm{C}$, then the zinc powder was added slowly, and the timing was started at the same time, the reaction time stayed for 60 min. At the end of the experiment, a right amount of reaction solution was taken, filtered, before it was cooled off, the sample was directly sent for analysis.

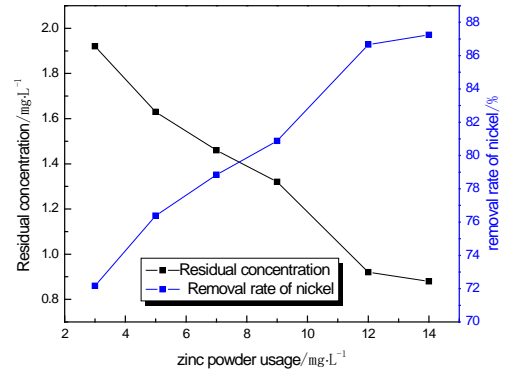

Fig.3 The influence of zinc powder usage on nickel purification separation

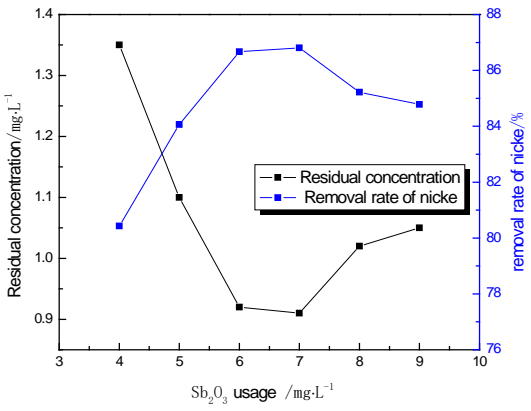

Fig.4 The influence of $\mathrm{Sb}_{2} \mathrm{O}_{3}$ usage on nickel purification separation

As Fig. 3 shows that more quantities of the nickel were removal with the usage of zinc increased. When the usage of zinc powder was $12 \mathrm{~g} / \mathrm{l}$, the removal rate of nickel would be $86.67 \%$. The nickel content in the solution was reduced to $0.92 \mathrm{mg} / \mathrm{l}$. when zinc powder usage up to $14 \mathrm{~g} / \mathrm{l}$, the removal rate of nickel was $87.25 \%$, and the nickel content in the solution was reduced to $0.88 \mathrm{mg} / \mathrm{l}$. In a conclusion, the usage of zinc powder was determined at $12 \mathrm{~g} / \mathrm{l}$ and could reach the experiments demands. The result could satisfy the need of the zinc electrowinning industrial standard.

\section{Antimony salt consumption study of actual solution purification separation in addition to the nickel test}

According to the above experiment results, the experiment temperature was determined at $95^{\circ} \mathrm{C}$, and the amount of zinc powder was $12 \mathrm{~g} / \mathrm{l}$. To determine the optimal usage, the amount addition of Sb2O3 was varied differently. A volume of $500 \mathrm{ml}$ pretreated solution was added into three-necked flask in the experiment, and the recycling water was turned on then and the lixivium was heated at this time with Sb2O3 adding. When the temperature was risen to $95^{\circ} \mathrm{C}$, zinc powder was added slowly with time starting at the same time. The reaction time was $60 \mathrm{~min}$. Some appropriate reacted solution was taken and then filtered and cooled off gradually, finally the analysis of the example was carried out.

Fig. 4 shows that the removal rate of nickel was increasing with more Sb2O3 addition. When the addition of $\mathrm{Sb} 2 \mathrm{O} 3$ is $6 \mathrm{mg} / \mathrm{l}$, the nickel content in the solution was reduced to $0.92 \mathrm{mg} / \mathrm{l}$ less than 1 $\mathrm{mg} / \mathrm{l}$. When the addition of Sb2O3 is $7 \mathrm{mg} / \mathrm{l}$, the nickel content in the solution was reduced to 0.91 $\mathrm{mg} / \mathrm{l}$. If the addition of Sb2O3 was continued to increase, the nickel content in the solution increased slowly. It was not conducive to zinc nickel separation. 
Table.3. Purify ions in solution before and after $/ \mathrm{mg} \cdot \mathrm{L}^{-1}$

\begin{tabular}{lllll}
\hline ions & $\mathrm{Cd}$ & $\mathrm{Cu}$ & $\mathrm{Ni}$ & $\mathrm{Sb}$ \\
\hline before & 400 & 410 & 640 & 14.56 \\
after & 0.6 & 0.1 & 0.91 & 10.67 \\
standard & $<1$ & $<0.1$ & $<1$ & $<0.1$ \\
\hline
\end{tabular}

The change of metal ions in the lixivium is shown in Table.3. It can be seen that the copper, cadmiun and nickle ions in the solution were all lower than the standard needed. The content of antimony was $14.56 \mathrm{mg} / \mathrm{l}$ before purification, and reduced to $10.67 \mathrm{mg} / \mathrm{l}$ after purification. However, despite the content of antimony was declined, it did not meet the requirements of zinc electrowinning $(<0.1 \mathrm{mg} / \mathrm{l})$.

In the process of zinc electrowinning, the antimony existence has great harm in the process, it can cause a large area of zinc cathode plate burning and it can also affect the quality of the zinc and reduce the current efficiency seriously. In the zinc industrial electrowinning, the content of antimony in zinc electrolyte solution is controlled below $0.1 \mathrm{mg} / \mathrm{l}$. This article does not do in-depth research. It still needs to be researched.

\section{Conclusions}

(1) The lixivium of slag of scrap copper smelting contains large amount of copper and cadmium ions. It needs to be pretreatment.

(2)The best experiment condition is reaction temperature $95^{\circ} \mathrm{C}$, the amount of zinc $12 \mathrm{~g} / \mathrm{l}$, the amount of Sb2O3 $6 \mathrm{mg} / \mathrm{l}$, the reaction time $60 \mathrm{~min}$. The residual content of nickel in the lixivium was $0.92 \mathrm{mg} / \mathrm{l}$. It is lower than the standard of the industrial electric deposition of zinc.

(3) After purification, $\mathrm{Cu}, \mathrm{Cd}$ and $\mathrm{Ni}$ ions in the solution were all lower than the standard needed content. Sb ion in the solution was not lower than $0.1 \mathrm{mg} / \mathrm{l}$. It can affect the quality of zinc and reduce current efficiency. This article does not do in-depth research. It still needs to be researched.

\section{References}

[1] Song Yunkun, Shen Qianghua, Zhong Zhong, “ Miscellaneous copper scrap recycling present situation and the countermeasures in China[J], ” Journal of Yunnan Metallurgy, 35 (6) (2006),1.

[2] Shen Shouwen, Chang Zhen, “Copper prepared renewable non-ferrous metal industry [J]," Journal of Ningbo, Energy Conservation, 3 (2010), 39-41.

[3] Lu Jian, “Development report about China renewable non-ferrous metal industry in 2009 [R],” Renewable Resources, 4 (2010), 24-27. 